\title{
1 Managing threats and restoring wetlands within catchments of the Great
}

\section{Barrier Reef, Australia}

3

4 Adame, $\mathrm{MF}^{1^{*}}$, Arthington $\mathrm{AH}^{1}$, Waltham $\mathrm{NJ}^{2}$, Hasan $\mathrm{S}^{1}$, Selles $\mathrm{A}^{3}$, Ronan $\mathrm{M}^{3}$.

5

$6 \quad{ }^{1}$ Australian Rivers Institute, Griffith University, Nathan, QLD, Australia

$7 \quad{ }^{2}$ Tropical Water \& Aquatic Ecosystem Research (TropWATER), College of Science and Engineering,

8 James Cook University, Townsville, QLD, Australia

$9 \quad{ }^{3}$ Department of Environment and Science, Wetland Team, Queensland Government, Brisbane, QLD,

10 Australia

11

12

13

*Corresponding author:

14

Maria Fernanda Adame

15

f.adame@griffith.edu.au

Australian Rivers Institute

170 Kessels Rd, Nathan, QLD, 4111

Australia 


\section{Abstract}

1. In the catchments of the Great Barrier Reef (GBR) in Australia, there are over a million hectares of wetlands, which help to sustain the health and resilience of the reef.

2. Here, we review the status, values, and threats of wetlands in the GBR catchments, as well as the management, protection, and the challenges and opportunities for their restoration and rehabilitation.

3. Currently, wetlands in the GBR catchments have low rates of area loss and are generally well protected. However, they face major management challenges due to the intensive land use of the catchments, especially grazing, agriculture, horticulture, and mining. Major threats to these wetlands include water pollution, invasive species, changes in hydrology, and increasing temperature and salinity from climate change.

4. In recent years wetlands have been considered primarily for their role in improving water quality to ameliorate contaminated terrestrial runoff to the GBR, with little attention given to their intrinsic values and other ecosystem services.

5. Financial opportunities for wetland restoration in addition to government-funded schemes include water pollution offsets, payment for ecosystem services, and nitrogen markets.

6. Wetlands need to be protected, managed, and restored for the ecosystem services they provide to the GBR, but also for their intrinsic value as significant features of coastal landscapes.

Keywords: invasive species; floodplains; mangroves; nitrogen; Queensland; rehabilitation; rivers; sea level rise 


\section{Introduction}

Wetlands are one of the most valuable ecosystems on Earth and are considered priority areas for conservation (Keddy et al., 2009). They are among the most threatened ecosystems on the Planet, as humans have historically exploited them for freshwater provision, sewage and solid waste disposal, aquaculture production, fertile arable land, and urban infrastructure (Junk et al., 2013). Over half of the world's wetlands have been lost (Davidson, 2014) and only $11 \%$ of the remaining wetlands have some level of protection (Reis et al., 2017).

The Great Barrier Reef (GBR) is the largest coral reef in the world with outstanding values that have conferred it the status of World Heritage Area. In the catchments of the GBR, there are over one million hectares of wetlands (WetlandInfo, 2017). These wetlands provide valuable ecosystem services, including some that directly serve the reef, such as improving water quality and sustaining coastal fisheries. Wetlands within the GBR catchments also have intrinsic values such as biodiversity and less known ecosystem values such as flooding mitigation and carbon storage (Waterhouse et al., 2017). These values have not been considered to the same degree as for other parts of the broader reef ecosystems, and in-depth knowledge on wetland condition, threats, and functions has been relatively poor (Australian and Queensland Government, 2016; Waterhouse et al., 2017).

In this review, the protection and management, as well as the challenges and opportunities for restoration and rehabilitation of wetlands within the GBR catchments are examined. To achieve this, information on the status, values, and threats to these wetlands were compiled. Additionally, the protection status, current management practices, and potential financial opportunities for wetland restoration were examined. This research will contribute to 
improving the conservation of this globally important region, where wetlands are essential for the health and resilience of the GBR.

\subsection{Wetland definition, extent, and types}

Wetlands in Queensland are defined as: "Areas of permanent or periodic/intermittent inundation with water that is static or flowing, fresh, brackish or salt" (WetlandInfo, 2017). They must have at least one of the following attributes: (1) Periodically supports plants or animals adapted and dependent on wet conditions for at least part of their life cycle; (2) the substratum is predominantly anaerobic, undrained soils that are saturated, flooded or ponded; and (3) the substratum is saturated, or covered by water at some time (WetlandInfo, 2017). From vegetation, soil, and long-term inundation mapping, wetland area within the GBR catchments has been estimated as 1,571,420 ha (WetlandInfo, 2017). The GBR catchments have at least 36 river basins divided into five regions: Cape York, Wet Tropics, Burdekin, Mackay-Whitsundays, Fitzroy, and Burnett-Mary region (Fig. 1a). Wetlands in the GBR catchments cover a wide range of climates from equatorial, tropical, subtropical, to arid and semiarid.

Wetlands are classified into the broad systems of lacustrine riverine, palustrine, estuarine and modified/ artificial by the Queensland Government consistent with Australia's and Ramsar classifications (Bino, Kingsford, \& Brandis, 2016; WetlandInfo, 2017; Fig. 1be). Riverine wetlands are contained within a channel (river, creek or waterway); palustrine wetlands include vegetated swamps that are non-riverine or non-channel systems with more than $30 \%$ cover of emergent vegetation; lacustrine wetlands are large, open, water-dominated systems (> 8ha); and estuarine wetlands are influenced by tidal inundation. Additionally, 
modified/artificial wetlands include human-made structures such as dams, constructed lagoons and irrigation channels, where the original hydrology has been modified extensively. Floodplains are not considered wetlands, but wetlands within floodplains were included if they fulfilled the definition of wetland, and are sometimes referred to as floodplain wetlands.

Within the GBR region, riverine wetlands comprise most of the area with 666,600 ha, followed by estuarine wetlands with 433,300 ha, palustrine wetlands with 281,600 ha, and lacustrine wetlands with 22,420 ha (WetlandInfo, 2017). Artificial and highly modified wetlands comprise 167,500 ha ( $10 \%$ of wetland area).

\section{Status and threats to wetlands within the GBR catchments}

Changes in the area of wetlands in the GBR catchments is assessed every four years (see Environmental Protection Agency 2005 for detailed methodology). Historically, large wetland losses occurred in the region (Bino et al., 2016), but recently, there has been a low net loss of natural wetland area $(<0.1 \%, 2005-2013)$ and an annual gain rate of $1 \%$ in artificial wetlands (WetlandInfo, 2017). However, degradation is a major issue (Bino et al., 2016; Waterhouse et al., 2017), with most wetlands considered to be in moderate condition (Australian and Queensland Government, 2016). The most significant impacts on wetlands of the GBR catchments are water pollution, invasive species, altered hydrological connectivity, and climate change.

\subsection{Water pollution: nutrients, sediments, and pesticides}

In the GBR catchments, $87 \%$ of the land (447,354.2 ha) is modified or intensively cultivated, primarily for grazing and dairy, but also for sugarcane production, horticulture, and mining (Geosciences Australia, 1997). These activities cause runoff of sediment, 


\section{5}

nutrients, pesticides, and other pollutants that flush into wetlands through surface runoff and groundwater drainage (Bainbridge, Brodie, Faithful, Sydes, \& Lewis, 2009, Waterhouse et al. 2017). Pollution loads to the GBR have increased substantially since pre-European settlement; total suspended solids have risen by 3 to 6-fold to 9,900 ktonnes per year, total nitrogen loads have risen 2 to 6-fold to 55 ktonnes per year, and total phosphorous has risen from 3 to 9-fold to 13 ktonnes per year (Kroon et al., 2012, Waterhouse et al. 2017).

The effects of water pollutants on wetlands in the GBR catchment are driven by pollutant loads, residence time, wetland area, and climate (Davis, Pearson, Brodie, \& Butler, 2016; Waterhouse et al., 2017). The GBR region comprises a range of climates, from the tropical wet north (> 3,000 mm per year) to the subtropical and drier south (500 $\mathrm{mm}$ per year; Australian Bureau of Meteorology, 2018). Most annual rainfall occurs during the wet season (December - May) when large amounts of pollutants are rapidly mobilised and transported downstream (Davis et al., 2016). During the dry season, low flushing, high nutrient loads, and large amounts of organic matter cause deterioration of water quality in many channel waterholes, floodplain lagoons, and lakes (Davis et al., 2016). Thus, wetlands within the GBR are threatened by extensive pulses of flood water carrying high pollutant loads during the wet season, and by chronic exposure to poorly flushed water during the dry season.

Excessive nutrients in the GBR region coupled with high temperatures have deteriorated the water quality, caused the excessive growth of algae and aquatic weeds (Pearson, Connolly, \& Boyero, 2015; Pearson et al., 2013), and decreased macroinvertebrate and fish diversity (Arthington, Godfrey, Pearson, Karim, \& Wallace, 2015; Mantyka-Pringle et al., 2014). Excess nitrogen has contributed to dieback of mangrove forests during periods of low rainfall (Lovelock, Ball, Martin, \& Feller, 2009). 
Nutrients can be transported in dissolved forms, but also as particles bound to suspended sediment. Increased sediment has caused loss of habitat of the native freshwater moray (Gymnothorax polyuranodon), a diadromous fish that lives within interstitial spaces among boulders (Ebner, Fulton, Donaldson, \& Schaffer, 2016). Increased turbidity can also decrease the diving duration of freshwater turtles (Elseya irwini; Schaffer, Hamann, Rowe, \& Burrows, 2016). Some invertebrate species in lowland streams of the GBR have shown resistance to high suspended sediments, at least in the short-term (Connolly \& Pearson, 2007). In estuarine wetlands, excessive sedimentation may increase mangrove areas in some locations, but also cause the death of trees in other areas where sediment buries seedlings and roots (Lovelock \& Ellison, 2007).

In addition to nutrients and sediments, pesticides are a significant source of stress for wetlands in the GBR region (Lewis et al., 2009). The most regularly reported herbicides are Photosystem II inhibitors (PSII; Smith et al., 2012) including atrazine, ametryn, hexazinone, tebuthiuron, and diuron (Lewis et al., 2009). Herbicides can affect the whole food chain. In benthic microalgae, PSII inhibiting herbicides reduce growth (Magnusson, Heimann, \& Negri, 2008) and modify diatom community composition (Wood, Mitrovic, Lim, \& Kefford, 2017). In amphibians and fish, atrazine causes osmoregulatory disturbance affecting gill histopathology, gonadal morphology, reproductive fitness, and the dynamics of fish populations (Kroon, Hook, Metcalfe, \& Jones, 2015). The long-term ecological effects of exposure to herbicides in the GBR region are currently poorly understood.

\subsection{Invasive species}


Wetland degradation caused by nutrient runoff and hydrological alteration favours the

establishment of invasive non-native macrophytes (Fig. 2a). The most prevalent species include hymenachne (Hymenachne amplexicaulis), paragrass (Urochloa mutica), salvinia (Salvinia molesta), cabomba (Cabomba caroliniana), water lettuce (Pistia stratiotes), and water hyacinth (Eichhornia crassipes; Mackay, James, \& Arthington, 2010; Werren, 2001). Invasive macrophytes reduce oxygen levels in the water column through the decrease in water surface aeration, a decrease in algal photosynthesis, and the increase in organic matter decomposition, all of which affect fish and invertebrates (Perna, Cappo, Pusey, Burrows, \& Pearson, 2012; Waltham \& Fixler, 2017). Although asphyxiation thresholds vary among species and life stages (Butler \& Burrows, 2007), hypoxia events during the summer months can cause extensive fish kills (Perna et al., 2012).

Many non-native aquatic and terrestrial vertebrates have spread throughout wetlands of the GBR catchments. Aquatic species include: cane toads (Bufos marinus) and several fish species such as Mozambique tilapia (Oreochromis mossambicus), gambusia (Gambuisa holbrooki), guppies (Poecilia reticulate), swordtails (Xiphorphorus hellerii), and platys (Xiphorphorus maculata) (Harrison \& Congdon, 2002; Pearson et al., 2015). Infestations of tilapia (O. mossambicus), and Black mangrove cichlid (Tilapia mariae) are prevalent in some wetlands of the GBR (Russell, Thuesen, \& Thomson, 2012; Fig. 2d), spreading through irrigation networks (Russell, Ryan, McDougall, Kistle, \& Aland, 2003). Tilapia displace native fish species and introduce diseases (Canonico, Arthington, McCrary, \& Thieme 2005; Russell et al., 2012). There is little information on the population size and distribution ranges of non-native species, and their ecological effects are mostly unknown (Sheaves et al., 2014). 
Terrestrial non-native vertebrates, such as pigs (Sus scrofa) and cattle cause some of the most significant impacts on wetlands of the GBR region (Fig. 2a, c). Pigs and cattle feed on saltmarsh and mangroves, increase nutrient concentrations and sediment resuspension in the water, and modify macrophyte communities (Doupé, Schaffer, Knott, \& Dicky, 2009; Pettit et al., 2012). These disturbances cause $\mathrm{pH}$ changes and anoxia, affecting the habitat of many animals, including freshwater turtles (Chelidae) and fish (Doupé et al., 2009; Waltham $\&$ Schaffer, 2018). Pigs can also affect the trophic chain as they feed directly on many native species such as freshwater turtles (Waltham \& Schaffer, 2018). In turn, pigs have become a new source of nutrition for crocodiles in the region (Adame et al., 2018).

\subsection{Altered hydrological connectivity}

One of the overarching factors affecting the biodiversity and ecological health of wetlands is hydrological connectivity (Bunn \& Arthington, 2002). In the GBR catchments, barriers such as tidal exclusion bunds, dams, weirs, roads, rail crossing, urban infrastructure, weirs, and aquatic plant blockages have altered hydrological connectivity (Karim et al., 2013). Groundwater extraction for mining and irrigation also threatens the hydrological connectivity of wetlands and could result in saltwater intrusion into freshwater habitats (Narayan, Schleeberger, \& Bristow, 2007). Fish recruitment in floodplain lagoons depends on flood dynamics (Godfrey, Arthington, Pearson, \& Karim, 2017), and hydrological alterations can disrupt nursery habitats and alter their life cycles (Sheaves, Baker, Nagelkerken, \& Connolly, 2015). the highly modified wetlands in the Burdekin delta support native fish species (Davis \& 
Moore, 2015), and small remnant riparian wetlands are important for bird biodiversity (Keir, Pearson, \& Congdon, 2015). Similarly, frequent water flushing of some floodplain lagoons in the Wet Tropics has maintained good water quality and relative high fish diversity, despite the variable connectivity with main river channels (Arthington et al., 2015). However, due to the lack of pre-impact baseline data, the long-term viability of fish populations and the full consequences of barriers and altered connectivity are unknown. depletion. Long periods of drought followed by large floods have been associated with severe "blackwater" events, where water poor in oxygen is flushed downstream causing the death of organisms in riverine and coastal ecosystems (Whitworth, Baldwin, \& Kerr, 2012).

\subsection{Climate change}

As temperatures increase, oxygen concentrations in the water column decrease, causing asphyxiation of aquatic animals which are unable to surface, respire, or escape (Butler \& Burrows, 2007). Increased temperature can cause both acute and chronic exposure effects in aquatic biota (Wallace, Waltham, Burrows, \& McJannet, 2015) by modifying the metabolic rate of fish, but also growth, resource allocation for reproduction, and population size (Jobling, 1995). (CSIRO, 2016). A decrease in precipitation could change river flow patterns, which may decrease connectivity, increase salinity, and decrease sediment supply (Bunn \& Arthington, 
2002; Gilman, Ellison, Duke, \& Field, 2008). The increase in frequency and severity of droughts and floods (CSIRO, 2016) will result in more severe and frequent blackwater events (Whitworth et al., 2012).

Tropical storms cause defoliation, abrasion, stem breakage, uprooting and sediment smothering of wetlands (Sanford et al., 1991). Additionally, prolonged inundation as a result of flooding may 'suffocate' some wetland species (McKee, 1996). However, tropical storms can also increase growth in mangrove forests, as high rainfall causes alleviation of hypersalinity, and increases nutrient delivery (Lovelock et al., 2011). In 2011, cyclone Yasi damaged $17 \%$ of the mangroves in Hinchinbrook Channel, especially those fringing the seaside (Asbridge, Lucas, Accad, \& Dowling, 2015). One year after the cyclone, a large proportion of the forest recovered (Asbridge et al., 2015), however, until now, some areas have not improved. The increase in the frequency and intensity of extreme weather events will modify community structure and productivity of mangroves (Lovelock, Cahoon, et al., 2015), favouring species that are tolerant to disturbances and have rapid regeneration (Baldwin, Egnotovich, Ford, \& Platt, 2001).

Sea level rise will impact wetlands, especially coastal wetlands (Lovelock \& Ellison, 2007). The response of estuarine wetlands to sea level rise will depend on their productivity, sediment supply, the grain size of the sediment, tidal range, and rainfall (Lovelock, Adame, et al., 2015). Intertidal wetlands in the mouths of rivers will rely on sediment supplied during high rainfall events to maintain elevation relative to sea level, while wetlands in islands far offshore will depend on root growth (Lovelock, Adame et al., 2015). According to a model for the Indo-Pacific, mangroves from the GBR catchments, where sediment supply is high, 
are at relatively low risk of being submerged by 2100 (Lovelock, Cahoon, et al., 2015).

261

262

Additionally, sea level rise will cause mangroves to migrate into saltmarsh or adjacent freshwater wetlands (Saintilan \& Rogers, 2013; Fig. 2b). Further acceleration of sea level rise may result in the loss of intertidal wetlands of the region (Lovelock, Cahoon, et al., 2015).

Increases in atmospheric $\mathrm{CO}_{2}$ will also contribute to changes in wetland vegetation.

For example, increase in $\mathrm{CO}_{2}$ will increase mangrove production, with limits set by changes in nutrients and salinity (Reef et al., 2015). It is possible that mangroves of the Avicennia genus will become dominant in areas where nutrients and salinity levels are high (Reef et al., 2016).

\section{Protection and management of wetlands in the GBR catchments}

Wetlands have been overexploited historically and are currently one of the worst protected and managed ecosystems on Earth (Kingsford, Basset, \& Jackson, 2016). In Australia, management and policy have been constrained by data on distribution, type and extent of wetlands in most states, but not in Queensland (Bino et al., 2016). In 1999, the Queensland Government endorsed the Strategy for the Conservation and Management of Queensland's wetlands with two main objectives: 1) the sustainable use and management of natural wetlands and integrated catchment practices; and 2) the development of community awareness to encourage community involvement in wetland management (State of Queensland, 2017). In 2003, The Queensland Wetlands Program was established by the Queensland and Australian Government to support projects and programs that enhance the wise use and sustainable management of Queensland's wetlands. The program delivers 
detailed mapping and classification of wetlands, planning, management, rehabilitation guidelines, monitoring and assessment, and communication material.

In the GBR catchments, wetlands are protected by laws passed by the Queensland and Commonwealth governments, but also through international obligations, such as Ramsar (Table 2, 3). In the GBR catchments about $17 \%$ of wetlands occur in protected areas or reserves (Table 2), and most of the high-value wetlands are protected through planning legislation (Table 3). Similar to other regions in the world, wetland protection in Queensland has not prevented their degradation, which requires catchment management solutions that support hydrological connectivity, adequate water quality and upstream pest control (Bino et al., 2016).

The Wetlands in the Great Barrier Reef Catchments Management Strategy 2016-21 (DEHP, 2016) supports the Reef 2050 Long-Term Sustainability Plan (Commonwealth of Australia, 2015) and the Reef Water Quality Improvement Plan 2017-2022 (State of Queensland, 2018) and outlines the activities required to manage wetlands in the GBR sustainably. As part of current management practices, wetland extent is monitored every four years, and recently, a program to monitor their condition has been established (Australian and Queensland Government, 2016). The focus of wetland management in recent years has been on their role in improving water quality by removing nutrients and sediment that otherwise would reach the GBR. However, recent activities have placed more focus on the intrinsic value of wetlands and their need for improved management (State of Queensland, 2018). Table 4 summarises management strategies for the threats that wetlands face in the GBR. 


\section{Wetland restoration}

On-ground activities have involved small to medium scale projects, for example, monitoring, managing and removing weeds and other invasive species, and removing bunds and other barriers for improving hydrological connectivity (WetlandInfo, 2014a, b, Table 4). Although some projects have been relatively successful, there is still a need to increase their scale to have a meaningful impact at the landscape level. Future restoration projects need clear objectives and goals, and it is important to acknowledge that wetland restoration can provide some, but not all, of the expected ecosystem services that wetlands are capable of delivering (Adame, Hermoso, Perhans, Lovelock, \& Herrera-Silveira., 2015).

Wetland restoration activities in Australia can come at a substantial cost to the private landholder or community organisation who owns the land. Landowners are incurring private restoration costs to deliver ecosystem services that in many cases also include public goods. Regulating services in particular (e.g. pollution assimilation) are non-excludable, i.e. it is not feasible to exclude individuals from receiving the ecosystem service once it has been made incentives to undertake wetland restoration.

Application of economic incentives for wetland restoration is increasing, and include offsets for nutrient and sediment pollution, payment for ecosystem services, and nitrogen and carbon markets (Waltham et al., 2017). Offset frameworks could provide economic support for wetland restoration. For example, nutrient discharges or dredging at one point could be offset by wetland restoration to improve water quality in the catchment (Bell, 2016). 
However, offsets for wetland restoration need to be based on demonstrable outcomes (i.e. wetland rehabilitation) and not on activities (removing non-native macrophytes; Bell, 2016). Additionally, damage in one wetland to restore another should only be used as the last resource, and wetland protection should always be prioritised over restoration (Maron, Gordon, Mackey, Possingham, \& Watson, 2015).

A complementary recommended approach to offsetting pollution and incentivising wetland restoration are payments for ecosystem services or PES (State of Queensland, 2016). PES is based on the concept that the 'consumer' of ecosystem services, or those who benefit from their supply, should pay the ecosystem service 'supplier' to cover the costs of production. Restoration activities with the aim of supplying a particular ecosystem service, such as improvements in water quality, could deliver additional environmental benefits such as biodiversity protection, fisheries production, coastal protection, climate regulation, and support a range of cultural, recreational and educational values (Adame et al., 2015).

Finally, nitrogen markets, or more generally water quality trading, have also been proposed as a possible economic mechanism for reducing nitrogen pollution in waterways and potentially incentivising wetland restoration (Smart et al., 2016). A tradable market approach encourages innovation and flexibility in complying with the regulations. Water quality trading is an emerging economic tool that is being considered by regulators around the world, notably New Zealand, countries fringing on the Baltic Sea, the United States of America, and could potentially be used in Australia to incentivize wetland restoration and rehabilitation (Greenhalgh \& Selman, 2012; Waltham et al., 2017). However, for a nitrogen market to be effective, it needs to have clearly-defined goals, a monitoring strategy, adequate 
market drivers, and stakeholder engagement (Greenhalgh \& Selman, 2012). A poorly designed nitrogen market can result in thin trading, thereby reducing environmental gains. challenges to overcome legacy deterioration caused by intense and diverse land uses in the catchments. In recent years wetlands have been managed primarily for the improvement of

361 water quality to the GBR, but their contribution still needs to be integrated into management 362 models and strategies (Wallace, Stewart, Hawdon, \& Keen, 2008). Future efforts need to be directed to the management and restoration of wetlands for their intrinsic values and broader contributions to healthy ecosystems in the GBR and its catchments. 
367 Acknowledgements

368 We acknowledge the Traditional Owners of the land, especially the Nywaigi, Djiru,

369 Girramay, and Gulnay people. We thank the Queensland Government through the Advance

370 Queensland Fellowship granted to MFA and the Great Barrier Reef Water Quality program

371 for their financial support. NW and MFA are funded by the Australian Government's

372 National Environmental Science Program, Tropical Water Quality Hub (Project 3.3.2). We

373 thank Paulina Kaniewska and Chris Pennay from the Queensland Herbarium for their useful

374 comments on early versions of this manuscript.

375

376

377

378 
References:

Adame, M. F., Jardine, T., Fry, B., Valdez, D., Linder, G., Nadji, J., \& Bunn S. (2018).

Estuarine crocodiles in a tropical coastal floodplain obtain nutrition from terrestrial prey. PLoS ONE, 13, e0197159.

Adame, M.F., Hermoso, V., Perhans, K., Lovelock, C. E., \& Herrera-Silveira, J. A. (2015). Selecting cost-effective areas for restoration of ecosystem services. Conservation Biology, 29, 493-502.

Arthington, A. H., Godfrey, P. C., Pearson, R. G, Karim F., \& Wallace, J. (2015).

Biodiversity values of remnant freshwater floodplain lagoons in agricultural catchments: evidence for fish of the Wet Tropics bioregion, northern Australia. Aquatic Conservation: Marine and Freshwater Ecosystems, 25, 336-352.

Asbridge, E., Lucas, R., Accad, A., \& Dowling, R. (2015). Mangrove response to environmental changes predicted under varying climates: case studies from Australia. Current Forestry Reports, 1, 178-194.

Australian Bureau of Meteorology, Australia Government. Viewed February 2018, http://www.bom.gov.au/

Australian and Queensland Government. (2016). Great Barrier Reef Report Card. Wetland condition results, Reef Water Quality Protecion Plan, Brisbane, Australia, 17pp. https://www.reefplan.qld.gov.au/measuring-success/report-cards/2016/assets/report-card-

\section{$\underline{\text { 2016-wetland-condition-results.pdf }}$}

Bainbridge, Z. T., Brodie, J. E., Faithful, J.W., Sydes, D. A., \& Lewis, S. E. (2009). Identifying the land-based sources of suspended sediments, nutrients and pesticides discharged to the Great Barrier Reef from the Tully-Murray Basin, Queensland, 

mangrove forests damaged by Hurricane Andrew. Plant Ecology, 157, 151-164.

Bell, J. (2016). Implementing an outcomes-based approach to marine biodiversity offsets: lessons from the Great Barrier Reef. Australasian Journal of Environmental Management, 23, 314-329.

Bino, G., Kingsford, R., \& Brandis, K. (2016). Australia's wetlands- learning from the past to manage for the future. Pacific Conservation Biology, 22, 116-129. altered flow regimes for aquatic biodiversity. Environmental Management, 30, 492-507. Butler, B., \& Burrows, D. (2007). Dissolved oxygen guidelines for freshwater habitats of northern Australia v1.0. Australian Centre for Tropical Freshwater Research, James Cook University, Townsville, Australia, 51pp introduced tilapias on native biodiversity. Aquatic Conservation Marine and Freshwater Ecosystems, 15, 463-483.

Connolly, N. M., \& Pearson, R. (2007). The effect of fine sedimentation on tropical stream macroinvertebrate assemblages: a comparison using flow-through artificial stream channels and recirculating mesocosms. Hydrobiologia, 592, 423-438.

Change in Australia. Projections for Australia's NRM regions. 
Davidson, N. C. (2014). How much wetland has the world lost? Long-term and recent trends in global wetland area. Marine and Freshwater Research, 65, 934-941.

Davis, A., Pearson, R., Brodie, J., \& Butler, B. (2016). Review and conceptual models of agricultural impacts and water quality in waterways of the Great Barrier Reef catchment area. Marine and Freshwater Research, 68, 1-19.

Davis, A. M., \& Moore, A. R. (2015). Conservation potential of artificial water bodies for fish communities on a heavily modified agricultural floodplain. Aquatic Conservation: Marine and Freshwater Ecosystems, 26, 1184-1196.

DEHP, Department of Environment and Heritage Protection, Wetlands Team, (2016). Queensland, Brisbane, Australia, 24

\section{pp.https://wetlandinfo.des.qld.gov.au/resources/static/pdf/management/policy/wetlands-}

\section{gbr-strategy2016-21v13.pdf}

Doupé, R., Schaffer, J., Knott, M., \& Dicky, P. (2009). A description of freshwater turtle habitat destruction by feral pigs in Tropical North-eastern Australia. Herpetological Conservation and Biology, 4, 331-339.

Ebner, B. C., Fulton, C. J., Donaldson, J. A., \& Schaffer, J. (2016). Distinct habitat selection by freshwater morays in tropical rainforest streams. Ecology of Freshwater Fish, 25, 329-335. 
Environmental Protection Agency (2005). Wetland mapping and classification methodology - overall framework - A method to provide baseline mapping and classification for wetlands in Queensland, Version 1.2, Queensland Government, Brisbane, Australia. ISBN 0975734466

Geosciences, Australia (1997). Australia’s River Basins. Viewed March, 2018

\section{http://eatlas.org.au/geonetwork/srv/eng/}

Gilman, E. L., Ellison, J., Duke, N. C., \& Field, C. (2008). Threats to mangroves from climate change and adaptation options: A review. Aquatic Botany, 89, 237-250.

Godfrey, P., Arthington, A., Pearson, R., \& Karim, F. J. W. (2017). Fish larvae and recruitment patterns in floodplain lagoons of the Australian Wet Tropics. Marine And Freshwater Research, 68, 964-979.

Greenhalgh, S., \& Selman, M. (2012). Comparing water quality trading progams: What lessons are there to learn? Regional analysis and policy, 42, 104-125.

Harrison, D., \& Congdon, B. (2002). Wet Tropics vertebrate pest risk assessment. School of Tropical Biology, James Cook University, Cairns, Australia, 47pp.

Jobling, M. (1995). Fish bioneregetics. Oceanographic Literature Review. London, U.K. Elsevier: Chapman \& Hall,

Junk, W. J., An, S., Finlayson, C., Gopal, B., Kvet, J., Mitchell, S., Mitsch, W., \& Robarts, R. (2013). Current state of knowledge regarding the world's wetlands and their future under global climate change: A synthesis. Aquatic Sciences, 75, 151-167.

Karim, F., Kinsey-Henderson, A., Wallace, J., Godfrey, P., Arthington, A. H., \& Pearson, R. G. (2013). Modelling hydrological connectivity of tropical floodplain wetlands via a combined natural and artificial stream network. Hydrological Processes, 28, 5696-5710. 

conservation priorities. BioScience, 59, 39-51.

Keir, A. F., Pearson, R. G., \& Congdon, R. A. (2015). Determinants of bird assemblage composition in riparian vegetation on sugarcane farms in the Queensland Wet Tropics. Pacific Conservation Biology, 21, 60-73.

Kingsford, R., Basset, A., \& Jackson, L. (2016). Wetlands: conservation's poor cousins. Aquatic Conservation: Marine and Freshwater Ecosystems, 26, 892-916. Abbott, B., ... Turner, R. D. R. (2012). River loads of suspended solids, nitrogen, phosphorus and herbicides delivered to the Great Barrier Reef lagoon. Marine Pollution Bulletin, 65, 167-181.

Kroon, F. J., Hook, S. E., Metcalfe, S., \& Jones, D. (2015). Altered levels of endocrine biomarkers in juvenile barramundi (Lates calcarifer; Bloch) following exposure to commercial herbicide and surfactant formulations. Environmental Toxicology and Chemistry, 34, 1881-1890.

Lewis, S., Brodie, J., Bainbridge, Z., Rohde, K., Davis, A., Masters, B., ... Schaffelke, B. (2009). Herbicides: A new threat to the Great Barrier Reef. Environmental Pollution, 157, 2470-2484.

Lovelock, C.E., \& Ellison, J. (2007). Part II: Species and species groups. Chapter 9: Vulnerability of mangroves and tidal wetlands of the Great Barrier Reef to climate change. In: Climate change and the Great Barrier Reef: A vulnerability assessment. Great Barrier Reef Marine Park Authority, Townsville. pp 239-269. 

increases mortality of mangroves. PloS ONE, 4, e5600. C. (2011). Intense storms and the delivery of materials that relieve nutrient limitations in mangroves of an arid zone estuary. Functional Plant Biology, 38, 514-522. R. (2015). Sea level and turbidity controls on mangrove soil surface elevation change. Estuarine, Coastal and Shelf Science, 153, 1-9. Reef, R., ... Triet, T. (2015). The vulnerability of Indo-Pacific mangrove forests to sealevel rise. Nature, 526, 559-563.

Mackay, S., James, C., \& Arthington, A. (2010). Macrophytes as indicators of stream condition in the Wet Tropics region, Northern Queensland, Australia. Ecological Indicators, 10, 330-340.

Magnusson, M., Heimann, K, \& Negri, A. (2008). Comparative effects of herbicides on photosynthesis and growth of tropical estuarine microalgae. Marine Pollution Bulletin, $56,1545-1552$.

Mantyka-Pringle, C., Martin, T., Moffat, D., Linke, S., \& Rhodes, J. (2014).

Understanding and predicting the combined effects of climate change and land-use change on freshwater macroinvertebrates and fish. Journal of Applied Ecology, 51, 572581. of biodiversity offsets. Nature Communications, 523, 401-403. 

seedlings to root zone hypoxia. Tree Physiology, 16, 883-889. Management, 89, 217-228. catchment: A challenge for assessment and monitoring. Marine and Freshwater Research, 64, 208-222.

Pearson, R. G., Connolly, N. M., \& Boyero, L. (2015). Ecology of streams in a biogeographic isolate- the Queensland Wet Tropics, Australia. Freshwater Biology, 34, 797-819.

Perna, C., Cappo, M., Pusey, B. J., Burrows, D., \& Pearson, R. G. (2012). Removal of aquatic weeds greatly enhances fish community richness and diversity: An example from the Burdekin River Floodplain, tropical Australia. River Research and Applications, 28, 1093-1104.

Pettit, N.E., Jardine, T.D., Hamilton, S.K., Sinnamon, V., Valdez, D., Davies, P.M., ... Bunn, S.E. (2012). Seasonal changes in water quality and macrophytes and the impact of cattle on tropical floodplain waterholes. Marine and Freshwater Research, 63, 788-800.

\section{Queensland Government, Queensland Legislation. 2018.}

\section{https://www.legislation.qld.gov.au/}

Reef, R., Winter, K., Morales, J., Adame, M. F., Reef, D. L., Lovelock, C. E. (2015). The effect of atmospheric carbon dioxide concentrations on the performance of the mangrove 
Reef, R., Slot, M., Motro, U., Motro, M., Motro, Y., Adame, M. F., ...Winter, K. (2016). The effects of $\mathrm{CO}_{2}$ and nutrient fertilisation on the growth and temperature response of the mangrove Avicennia germinans. Photosynthesis Research, 129, 159-170. 67, 523-533.

Russell, D., Ryan, T., McDougall, A., Kistle, S., \& Aland, G. (2003). Species diversity and spatial variation in fish assemblage structure of streams in connected tropical catchments in northern Australia with reference to the occurrence of translocated and exotic species. Marine and Freshwater Research, 54, 813-824.

Russell, D., Thuesen, P., \& Thomson, F. (2012). A review of the biology, ecology, distribution and control of Mozambique tilapia, Oreochromis mossambicus (Peters 1852) (Pisces: Cichlidae) with particular emphasis on invasive Australian populations. Reviews in Biology and Fisheries, 22, 533-554.

Saintilan, N., \& Rogers, K. (2013). The significance and vulnerability of Australian saltmarshes: Implications for management in a changing climate. Marine and Freshwater Research, 64, 66-79.

Sanford, R. L., Parton, W. J., Ojima, D. S., \& Lodge, D. J. (1991). Hurricane effects on soil organic matter dynamics and forest production in the Luquillo Experimental Forest, Puerto Rico: Results of simulation modeling. Biotropica, 23, 364-372.

Schaffer, J. R., Hamann, M., Rowe, R., \& Burrows D. W. (2016). Muddy waters: the influence of high suspended-sediment concentration on the diving behaviour of a 
Sheaves, M., Brookes, J., Coles, R., Freckleton, M., Groves, P., Johnston, R., \& Winberg,

P. (2014). Repairs and revitalisation of Australia's tropical estuaries and coastal wetlands:

Opportunities and constraints for the reinstatement of lost function and productivity. Marine Policy, 47, 23-38. Coasts, 38, 401-414. tradable permit scheme for cost-effective reduction of nitrogen runoff in the sugarcane catchments of the Great Barrier Reef. Report to the National Environmental Science Programe. Cairns, Australia, 75pp.

Smith, R., Middlebrook, R., Turner, R., Huggins, R., Vardy, S, \& Warne, M. (2012). Integrated Monitoring, Modelling and Reporting Program. Marine Pollution Bulletin, 65, $117-127$.

State of Queensland (2016). Final report of the the Great Barrier Reef Water Science Taskforce and the Office of the Great Barrier Reef, Brisbane, Australia, 94pp.

State of Queensland (2017). Environmental Protection Agency Strategy for the Conservation and Management of Queensland Wetlands 1999. 18 pp.

State of Queensland (2018). Reef Water Quality Improvement Plan 2017-2022. Brisbane, Australia. 56 pp. https://www.reefplan.qld.gov.au/about/assets/reef-2050-water-quality- 
Wallace, J., Stewart, L., Hawdon, A., \& Keen, R. (2008). The role of coastal floodplains in generating sediment and nutrient fluxes to the Great Barrier Reef lagoon in Australia. Ecohydrology and Hydrobiology, 8, 183-194.

Wallace, J., Waltham, N., Burrows, D., \& McJannet, D. (2015). The temperature regimes of dry-season waterholes in tropical northern Australia: Potential effects on fish refugia. Freshwater Science, 34, 663-678.

Waltham, N., \& Schaffer, J. (2018). Thermal asphyxia exposure risk to freshwater fish in feral-pig damaged tropical wetlands. Journal of Fish Biology, 93, 723-728

Waltham, N. J., \& Fixler S. (2017). Aerial herbicide spray to control invasive water Hyacinth (Eichhornia crassipes): Water quality concerns fronting fish occupying a tropical floodplain wetland. Tropical Conservation Science, 10, 1-10. J. (2017). Scoping land conversion options for high DIN risk, low-lying sugarcane, to alternative use for water quality improvement in Wet Tropics catchments. Report to the National Environmental Science Programme. Reef and Rainforest Research Centre Limited, Cairns, Australia. 170pp.

Waterhouse, J., Schaffelke, B., Bartley, R., Eberhard, R., Brodie, J., Star, M., ... Kroon, F. (2017). Scientific Consensus Statement. Land use impacts on Great Barrier Reef water quality and ecosystem condition. The State of Queensland, Brisbane, Australia, 18pp. Authority, Cairns, Australia, 94pp. 
WetlandInfo, 2014a. Department of Environment and Heritage Protection, DEHP,

610 Queensland, Invasive pest and weed awareness, education and control. Viewed 8 March

6112018 https://wetlandinfo.ehp.qld.gov.au/wetlands/resources/tools/wetland-

612 project/invasive-pest-and-weed-awareness-education-and-control-c191/.

613 WetlandInfo, 2014b. Department of Environment and Heritage Protection, DEHP,

614 Queensland. Revitalising Estuaries: Jerona Bund. Viewed 8 March 2018,

615 https://wetlandinfo.ehp.qld.gov.au/wetlands/resources/tools/wetland-project/revitalising-

616 estuaries-jerona-bund-b8f2/

617 WetlandInfo, 2017. State of Queensland, Department of Environment and Heritage

618 Protection, DEHP. https://wetlandinfo.ehp.qld.gov.au/

619 Whitworth, K. L., Baldwin, D. S., \& Kerr, J. L. (2012). Drought, floods and water

620 quality: Drivers of a severe hypoxic blackwater event in a major river system (the

621 southern Murray-Darling Basin, Australia). Journal of Hydrology, 450-451, 190-198.

622 Wood, R. J., Mitrovic, S. M., Lim, R. P., Kefford, B. J. (2017). Chronic effects of atrazine

623 exposure and recovery in freshwater benthic diatoms from two communities with

624 different pollution histories. Aquatic Toxicology, 189, 200-208.

625 
628 Fig. 1 Catchment area of the Great Barrier Reef (grey) in Queensland, northeast of Australia, 629 and main bioregions (Cape York, Wet Tropics, Burdekin, Mackay-Whitsundays, Fitzroy, 630 Burnett-Mary), and representative wetlands of the region: a) estuarine wetlands, mangroves 631 at Cardwell, b) riverine wetlands in the Murray River, c) palustrine wetlands- Melaleuca sp 632 forests and marsh at Girramay National Park, and d) lacustrine wetlands at Mungalla Station, 633 Herbert River. Photos by M.F. Adame.

634

635 Fig. 2 a) Wetlands invaded by non-native grass Hymenachne amplexicaulis and affected by 636 loss of riparian vegetation and cattle grazing, b) dying of Melaleuca forests in Halifax Bay 637 Wetlands National Park as mangroves encroach (green vegetation in the background) probably 638 due to salinization, c) feral pigs congregate in permanent water holes, d) Mozambique tilapia 639 (Oreochromis mossambicus), a significant non-native invasive species in wetlands of tropical 640 Australia. Photos by (a,b) M. F. Adame, (c) B. Ross, and (d) S. Westley. 
644 other types of wetlands.

\begin{tabular}{|c|c|c|c|}
\hline & Wetland Type & Area (ha) & $\%$ \\
\hline Riverine & & 666,600 & 42.4 \\
\hline Estuarine & Mangroves & 246,200 & 15.7 \\
\hline & Salt flats and saltmarsh & 187,100 & 11.9 \\
\hline Palustrine & Arid and semi-arid non floodplain tree swamp & 17,910 & 1.1 \\
\hline & Arid and semi-arid floodplain tree swamp & 21,130 & 1.3 \\
\hline & $\begin{array}{l}\text { Coastal and sub-coastal non-floodplain tree swamp- } \\
\text { Melaleuca and Eucalyptus spp. }\end{array}$ & 32,580 & 0.6 \\
\hline & Coastal and sub-coastal floodplain tree swamp & 61030 & 20 \\
\hline & Melaleuca and Eucalyptus spp. & & \\
\hline & $\begin{array}{l}\text { Coastal and sub-coastal non-floodplain grass/sedge } \\
\text { and herb swamp }\end{array}$ & 19,370 & 1.2 \\
\hline & $\begin{array}{l}\text { Coastal and sub-coastal non-floodplain wet heath } \\
\text { swamp }\end{array}$ & 17,090 & 1.1 \\
\hline & $\begin{array}{l}\text { Coastal and sub-coastal floodplain grass, sedge, herb } \\
\text { swamp }\end{array}$ & 87,880 & 5.6 \\
\hline & Coastal and sub-coastal saline swamp & 11,660 & 0.7 \\
\hline Lacustrine & & 22,420 & 1.4 \\
\hline $\begin{array}{l}\text { Artificial and } \\
\text { highly modified }\end{array}$ & & 162,620 & 10.3 \\
\hline
\end{tabular}


647 Table 2. Protection status of wetlands within the Great Barrier Reef catchments. Some 648 wetlands have multiple protection status so areas can overlap (WetlandInfo, 2017).

\begin{tabular}{|l|r|r|}
\hline \multicolumn{1}{|c|}{ Protection status } & Area (ha) & \% total \\
\hline World Heritage & 91,301 & 5.8 \\
Ramsar & 35,348 & 2.2 \\
National Park & 113,386 & 8.5 \\
Conservation Park & 10,504 & 0.7 \\
Forest Reserve & 250 & 0.02 \\
Resource Reserve & 2,437 & 0.2 \\
State Forest & 19,100 & 1.2 \\
Timber Reserve & 42 & 0.003 \\
\hline
\end{tabular}

649

650 


\begin{tabular}{|c|c|}
\hline \multicolumn{2}{|c|}{ International conventions and agreements } \\
\hline $\begin{array}{l}\text { United Nations Convention on } \\
\text { Biological Diversity }\end{array}$ & $\begin{array}{l}\text { Legally binding global treaty for the development of conservation and } \\
\text { sustainable use of biological diversity, including wetlands, and equitable } \\
\text { sharing of benefits. }\end{array}$ \\
\hline Ramsar Convention & $\begin{array}{l}\text { Australia as a signatory is required to describe and maintain the ecological } \\
\text { condition of the wetland. In the GBR, there are two Ramsar wetlands: } \\
\text { Shoalwater/Corio Bay, and Bowling Green Bay }\end{array}$ \\
\hline World Heritage & $\begin{array}{l}\text { The GBR is considered a World Heritage site as an outstanding example of } \\
\text { the world's natural and cultural heritage. Wetlands included in the GBR are } \\
\text { overseen by the World Heritage Committee, on behalf of United Nations } \\
\text { Educational, Scientific and Cultural Organisation (UNESCO). }\end{array}$ \\
\hline $\begin{array}{l}\text { The East Asian-Australasian } \\
\text { Flyway Partnership }\end{array}$ & $\begin{array}{l}\text { Voluntary partnership to facilitate collaborative efforts to protect migratory } \\
\text { birds, the wetlands they depend on, and livelihoods }\end{array}$ \\
\hline $\begin{array}{l}\text { Bonn convention (The } \\
\text { Convention on the Conservation } \\
\text { of Migratory Species of Wild } \\
\text { Animals) }\end{array}$ & $\begin{array}{l}\text { Aims to protect animal species which undergo migration across international } \\
\text { boundaries, such as many wetland-dependent birds. }\end{array}$ \\
\hline JAMBA/CAMBA/RoKAMBA & $\begin{array}{l}\text { Bilateral agreements with Japan, China, and Republic of Korea, respectively, } \\
\text { to protect migratory birds and the wetlands they depend on }\end{array}$ \\
\hline \multicolumn{2}{|c|}{ National Legislation and Policy } \\
\hline $\begin{array}{l}\text { Environmental Protection and } \\
\text { Biodiversity Conservation Act } \\
1999\end{array}$ & $\begin{array}{l}\text { Legal framework to protect and manage important flora, fauna and ecological } \\
\text { communities, including wetlands. }\end{array}$ \\
\hline $\begin{array}{l}\text { Australia's Biodiversity } \\
\text { Conservation Strategy 2010-2030 }\end{array}$ & Framework to conserve national biodiversity. \\
\hline $\begin{array}{l}\text { The Australian Government's } \\
\text { Threatened Species Strategy }\end{array}$ & Plan to prioritise effort and work in partnerships to reverse species in decline. \\
\hline $\begin{array}{l}\text { Australian Pest Animal Strategy } \\
2017-2027\end{array}$ & $\begin{array}{l}\text { Guidance on best practice for vertebrate invasive non-native animal } \\
\text { management. }\end{array}$ \\
\hline
\end{tabular}




\begin{tabular}{|c|c|}
\hline $\begin{array}{l}\text { Australian Weeds Strategy } 2017- \\
2027\end{array}$ & Guidance on best practice for invasive non-native plant management. \\
\hline \multicolumn{2}{|l|}{ State Legislation and Policy } \\
\hline Planning Act 2016 & $\begin{array}{l}\text { The legal framework for land use planning, development assessment and } \\
\text { dispute resolution. Deals with matters relating to wetlands }\end{array}$ \\
\hline $\begin{array}{l}\text { Nature Conservation (Wildlife) } \\
\text { Regulation } 2006\end{array}$ & Provides for the protection of native wildlife, including those of wetlands. \\
\hline $\begin{array}{l}\text { Vegetation Management Act } \\
1999\end{array}$ & Regulates the clearing of native vegetation. \\
\hline Water Act 2000 & Legislation for the sustainable planning and management of water resources. \\
\hline $\begin{array}{l}\text { Environmental Protection Act } \\
1994\end{array}$ & $\begin{array}{l}\text { A key element of the environmental legal system, which protects wetlands } \\
\text { while allowing development. }\end{array}$ \\
\hline Nature Conservation Act 1992 & $\begin{array}{l}\text { Conservation of nature allowing for the involvement of indigenous people. It } \\
\text { regulates clearing, growing, harvesting and trading of plants. }\end{array}$ \\
\hline $\begin{array}{l}\text { Marine Act 1994/ Fisheries Act } \\
1994\end{array}$ & Protects important estuarine wetlands. \\
\hline $\begin{array}{l}\text { Coastal Protection Management } \\
\text { Act } 1995\end{array}$ & Provides protection and management of coastal wetlands. \\
\hline Biosecurity Act 2014 & $\begin{array}{l}\text { Framework and powers for improved management of invasive non-native } \\
\text { plants and animals. }\end{array}$ \\
\hline Environmental Offsets Act 2014 & $\begin{array}{l}\text { Framework for which certain impacts on wetlands can be compensated for } \\
\text { elsewhere }\end{array}$ \\
\hline $\begin{array}{l}\text { Environmental Protection } \\
\text { (Water) Policy } 2009\end{array}$ & Establishes environmental values and water quality objectives for wetlands. \\
\hline \multicolumn{2}{|l|}{ Local Programs } \\
\hline Council Planning Schemes & Wetland management and restoration commitments of local councils \\
\hline $\begin{array}{l}\text { Natural Resource Management } \\
\text { Groups }\end{array}$ & $\begin{array}{l}\text { Non-regulatory programs for regional management and rehabilitation of } \\
\text { wetlands }\end{array}$ \\
\hline
\end{tabular}


Table 4. Management of threats in wetlands of the Great Barrier Reef catchments.

\begin{tabular}{|c|c|c|}
\hline Threat & Type & Management \\
\hline \multirow[t]{3}{*}{ Water pollution $^{1,2}$} & Nutrients & $\begin{array}{l}\text { Buffer zones: conservation and revegetation of wetlands. } \\
\text { Storm and drainage management. } \\
\text { Point source licensing and enforcement. } \\
\text { Best management fertiliser application methods: subsurface } \\
\text { application, appropriate rates for plant growth and soil levels, and } \\
\text { avoiding application during or before rain. } \\
\text { Treatment systems. } \\
\text { Fire management plans. } \\
\text { Education. }\end{array}$ \\
\hline & Sediments & $\begin{array}{l}\text { Streambank remediation. } \\
\text { Gully remediation. } \\
\text { Land cover management. } \\
\text { Stock management: controlled grazing, fencing wetlands, adequate } \\
\text { stocking regimes. } \\
\text { Cropping management: cover crops, trash blanketing, filter strips, } \\
\text { minimising or reducing tillage. } \\
\text { Fire management plans. } \\
\text { Education. }\end{array}$ \\
\hline & Pesticides & $\begin{array}{l}\text { Buffer zones. } \\
\text { Government regulation. } \\
\text { Incentivise organic farming. } \\
\text { Point source licencing and enforcement. } \\
\text { Best management application: rates and timing. } \\
\text { Spill prevention and control/response plans. } \\
\text { Education. }\end{array}$ \\
\hline Invasive species ${ }^{3}$ & Macrophytes & $\begin{array}{l}\text { Removal: manual, herbicide application, controlled fire. } \\
\text { Preventing dispersal. } \\
\text { Monitoring and reporting of sighting. } \\
\text { Movement restrictions, importation and quarantine practices (state } \\
\text { and national). } \\
\text { Education. }\end{array}$ \\
\hline
\end{tabular}




\begin{tabular}{|c|c|c|}
\hline & Fish & $\begin{array}{l}\text { Aquaculture best management practices. } \\
\text { Monitoring and reporting of sighting. } \\
\text { Monitoring of invasive species. } \\
\text { Manual eradication as euthanasia or poisoning in ponds and small } \\
\text { dams. } \\
\text { Education. }\end{array}$ \\
\hline & Cattle/horses & $\begin{array}{l}\text { Fencing wetlands. } \\
\text { Buffer zone between grazing areas and wetlands. } \\
\text { Education. }\end{array}$ \\
\hline & Pigs & $\begin{array}{l}\text { Eradication program: aerial shooting, trapping, poisoning. } \\
\text { Fencing wetlands. } \\
\text { Education. }\end{array}$ \\
\hline $\begin{array}{l}\text { Altered hydrological } \\
\text { regime }^{1,2}\end{array}$ & & $\begin{array}{l}\text { Bund/levee removal. } \\
\text { Drain regulation. } \\
\text { Environmental flow release. } \\
\text { Government regulation: water extraction licences, legislation and } \\
\text { policies regarding reclamation and drainage activities. } \\
\text { Water resource plans. } \\
\text { Fish passages. }\end{array}$ \\
\hline Climate change $^{1,2}$ & $\begin{array}{l}\text { Increase in } \\
\text { temperature }\end{array}$ & $\begin{array}{l}\text { Increase connectivity of waterholes. } \\
\text { Decrease pig and cattle disturbances that increase turbidity and } \\
\text { increase water temperature. } \\
\text { Increase riparian vegetation }\end{array}$ \\
\hline & $\begin{array}{l}\text { Rainfall } \\
\text { variation }\end{array}$ & Increase wetland connectivity. \\
\hline & $\begin{array}{l}\text { Intense } \\
\text { tropical storms }\end{array}$ & $\begin{array}{l}\text { Protect/revegetate coastal wetlands. } \\
\text { Increase floodplain connectivity. }\end{array}$ \\
\hline & Sea level rise & $\begin{array}{l}\text { Buffers zones to allow terrestrial migration of estuarine wetlands. } \\
\text { Monitor changes in salinity. }\end{array}$ \\
\hline
\end{tabular}

